\title{
Candida halmiae sp. nov., Geotrichum ghanense sp. nov. and Candida awuaii sp. nov., isolated from Ghanaian cocoa fermentations
}

Correspondence

Dennis S. Nielsen dn@life.ku.dk

\author{
Dennis S. Nielsen, Mogens Jakobsen and Lene Jespersen
}

Department of Food Science, Food Microbiology, Center for Advanced Food Studies (LMC), Faculty of Life Sciences, University of Copenhagen, Denmark
Cocoa beans, the principal raw material of chocolate, have to be fermented, dried and roasted to obtain the characteristic cocoa flavour and taste. The fermentation of cocoa is a microbiologically complex process involving the activities of yeasts, lactic acid bacteria and acetic acid bacteria with yeasts being particularly important during the initial phases of the fermentation process (Schwan \& Wheals, 2004; Jespersen et al., 2005; Nielsen et al., 2007). During an investigation of the micro-organisms involved in the fermentation of cocoa beans, a number of yeast isolates with unusual pheno- and

Abbreviation: Rep-PCR, repetitive palindromic polymerase chain reaction.

The GenBank/EMBL/DDBJ accession numbers for the 26S rRNA gene sequences of Candida halmiae sp. nov. G3 ${ }^{\top}$, Geotrichum ghanense sp. nov. G6 ${ }^{\top}$ and Candida awuaii sp. nov. G15 ${ }^{\top}$ are DQ466525, DQ.466527 and EU876854, respectively.

Supplementary figures showing (GTG) 5 -PCR fingerprints and corresponding dendrograms, derived from UPGMA linkage of correlation coefficients, for the three novel species are available with the online version of this paper. genotypic properties were isolated from malt extract agar (Nielsen et al., 2007). Preliminary pheno- and genotypic results showed that the isolates clustered in three distinct groups, all representing putatively novel yeast species. This study presents the morphological, biochemical and molecular characterization of these isolates. Group A consisted of a single isolate $\left(\mathrm{G} 3^{\mathrm{T}}=\right.$ CBS $11009^{\mathrm{T}}=$ CCUG $\left.56721^{\mathrm{T}}\right)$, group $\mathrm{B}$ comprised two isolates $\left[\mathrm{G}^{\mathrm{T}}\left(=\mathrm{CBS} 11010^{\mathrm{T}}=\right.\right.$ CCUG $\left.56722^{\mathrm{T}}\right)$ and G17] and group C contained four isolates $\left[\mathrm{G} 15^{\mathrm{T}}(=\mathrm{CBS}\right.$ $11011^{\mathrm{T}}=$ CCUG $56723^{\mathrm{T}}$ ), G68, G71 and G174]. All isolates were isolated during the first $12 \mathrm{~h}$ of cocoa fermentation and represented between 3 and $14 \%$ of the total yeast biota at the time of sampling (Nielsen et al., 2007).

All isolates and reference strains were grown in YPG broth [yeast extract $5 \mathrm{~g} \mathrm{l}^{-1}$ (Merck), glucose $10 \mathrm{~g} \mathrm{l}^{-1}$, peptone $10 \mathrm{~g} \mathrm{l}^{-1}, \mathrm{pH}$ 5.6] at $25{ }^{\circ} \mathrm{C}$ for $2-14$ days. For long-term storage, $20 \%$ glycerol was added to the medium and cultures were stored at $-80{ }^{\circ} \mathrm{C}$.

The micro morphology of the isolates grown for 1-5 days in YM (yeast extract $3 \mathrm{~g} \mathrm{l}^{-1}$, malt extract $3 \mathrm{~g} \mathrm{l}^{-1}$, peptone 
$5 \mathrm{~g} \mathrm{l}^{-1}$, glucose $\left.10 \mathrm{~g} \mathrm{l}^{-1}, \mathrm{pH} 5.6\right)$ and YPG broth $\left(25^{\circ} \mathrm{C}\right)$ was determined using phase-contrast microscopy (Fig. 1). Colony morphology was determined after 4-14 days of growth on YGP and MYGP agar $\left(25^{\circ} \mathrm{C}\right)$. Spore formation was examined on YM agar, V8 agar, 5\% malt agar and acetate agar (Robert et al., 2008) incubated for 4-28 days $\left(20\right.$ and $25{ }^{\circ} \mathrm{C}$ ). Spore formation was determined using bright-field microscopy. None of the isolates investigated produced ascospores.

The carbohydrate assimilation and fermentation patterns of the new isolates were determined following the protocol of Yarrow (1998) aided by use of the API ID32C identification system (bioMérieux). The results of these analyses are presented in Tables 1,2 and 3 and the species descriptions.
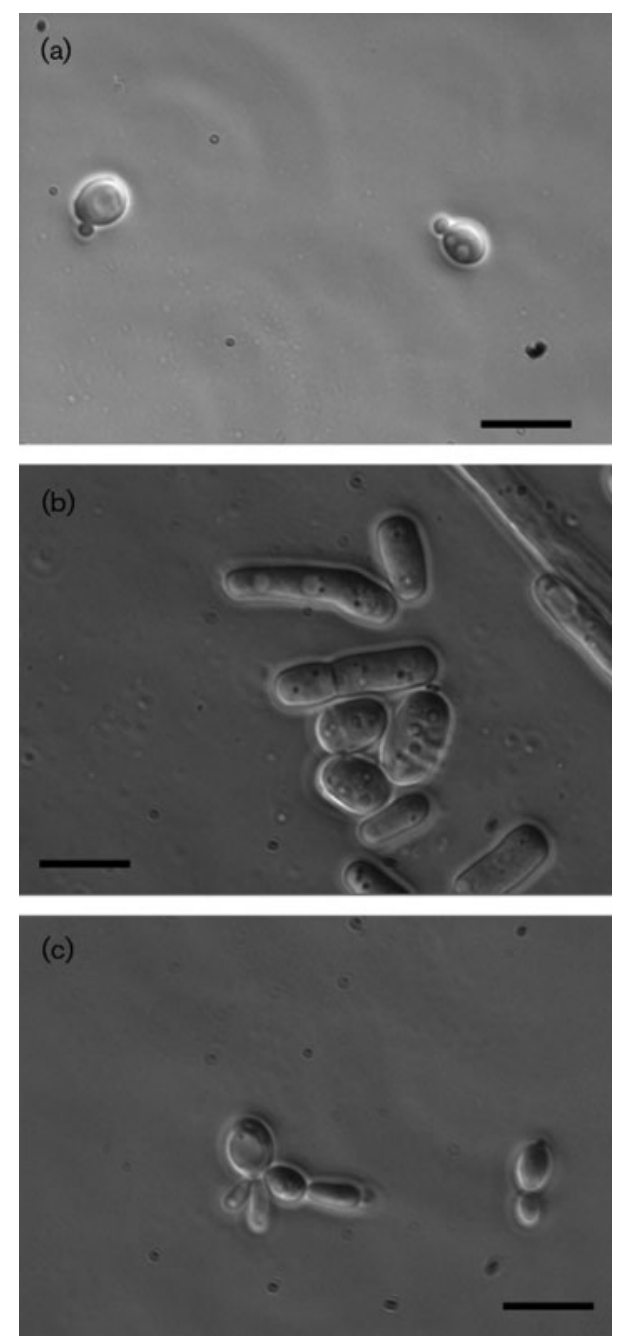

Fig. 1. Phase-contrast micrographs of cells of (a) Candida halmiae sp. nov. $\mathrm{G}^{\top}$; (b) Geotrichum ghanense sp. nov. $\mathrm{G}^{\top}$ and (c) Candida awuaii sp. nov. $\mathrm{G} 15^{\top}$ grown in YPG broth for 3 days. Bars, $10 \mu \mathrm{m}$.
Table 1. Key phenotypic characteristics of Candida halmiae sp. nov. and its closest phylogenetic relatives

Taxa: 1, Candida halmiae sp. nov.; 2, Candida diversa; 3, Candida silvae; 4, Saturnispora ahearnii; 5, Saturnispora besseyi; 6, Saturnispora dispora; 7, Saturnispora hagleri; 8, Saturnispora mendoncae; 9, Saturnispora saitoi; 10, Saturnispora zaruensis. +, Positive; -, negative; v, variable, strain dependent; $s$, slow; w, weak. Data partially adopted from Kurtzman (1998a), Meyer et al. (1998), Morais et al. (2005) and Kurtzman (2006).

\begin{tabular}{|lcccccccccc|}
\hline Characteristic & $\mathbf{1}$ & $\mathbf{2}$ & $\mathbf{3}$ & $\mathbf{4}$ & $\mathbf{5}$ & $\mathbf{6}$ & $\mathbf{7}$ & $\mathbf{8}$ & $\mathbf{9}$ & $\mathbf{1 0}$ \\
\hline $\begin{array}{l}\text { Assimilation of: } \\
\text { Cellobiose }\end{array}$ & $\mathrm{W}$ & - & - & - & - & - & - & - & - & - \\
Glycerol & - & $\mathrm{V}$ & + & - & - & - & $\mathrm{S}$ & $\mathrm{V}$ & - & - \\
Maltose & $\mathrm{S}$ & - & - & - & - & - & - & - & - & - \\
DL-Lactic acid & + & - & $\mathrm{V}$ & + & + & $\mathrm{W}-$ & + & + & + & + \\
Trehalose & $\mathrm{W}$ & - & - & - & - & + & + & - & + & + \\
D-Xylose & $\mathrm{W}$ & $\mathrm{V}$ & - & - & - & - & - & - & - & - \\
& & & & & & & & & &
\end{tabular}

For 26S rRNA gene sequencing, DNA was extracted using the Instagene Matrix DNA isolation kit following the manufacturer's instructions (Bio-Rad). The D1/D2 region of the 26S rRNA gene was amplified using primers NL1 and NL4 as outlined previously (Jespersen et al., 2005). Following purification (Qiagen PCR Purification kit), the fragments were sequenced in both directions by a commercial sequencing facility (DNA Technology, Aarhus, Denmark). Sequences were manually corrected and aligned using Vector NTI Suite 10 software (Informax). The closest phylogenetic relatives were determined by aligning the corrected sequences to $26 \mathrm{~S}$ rRNA gene sequences in the GenBank database using the BLAST algorithm (Altschul et al., 1997).

Comparison of the similarity of the 26S rRNA gene sequence (D1/D2 region) of isolate $\mathrm{G} 3^{\mathrm{T}}$ with type strains from the GenBank database revealed that isolate $\mathrm{G} 3^{\mathrm{T}}$ was most closely related to Saturnispora mendoncae [26S rRNA gene (D1/D2 region) gene sequence similarity 92.4\%], Saturnispora besseyi (88.8\%), Saturnispora saitoi (88.8\%) and Saturnispora ahearnii (88.3\%). Isolates G6 ${ }^{\mathrm{T}}$ and G17 were most closely related to Dipodascus albidus (86.2\%), Dipodascus geniculatus (85.3\%) and Dipodascus australiensis (84.7\%). Isolates G15 ${ }^{\mathrm{T}}$, G68, G71 and G174 were most closely related to Candida rugopelliculosa (92.3\%), Pichia occidentalis (91.6\%) and Pichia exigua (91.9\%). Until recently Pichia occidentalis and Pichia exigua were considered to belong to the genus Issatchenkia. However, convincing phylogenetic evidence that the genus Issatchenkia should be transferred to the genus Pichia was recently published (Kurtzman et al., 2008); this nomenclature is used in the present manuscript.

The 26S rRNA gene sequences (D1/D2 region) of the new isolates and their closest phylogenetic relatives retrieved from the GenBank database were aligned and phylogenetic trees were constructed by the neighbour-joining method 
Table 2. Key phenotypic characteristics of Geotrichum ghanense sp. nov. and its closest phylogenetic relatives

Taxa: 1, Geotrichum ghanense sp. nov.; 2, Geotrichum silvicola; 3, Geotrichum klebahnii; 4, Galactomyces geotrichum; 5, Dipodascus albidus; 6, Dipodascus armillariae; 7, Dipodascus australiensis; 8, Dipodascus geniculatus; 9, Dipodascus macrosporus. +, Positive; -, negative; $v$, variable, strain dependent; $\mathrm{w}$, weak; ND, not determined. Data partially adopted from de Hoog et al. (1998a, b, c) and Pimenta et al. (2005).

\begin{tabular}{|lccccccccc|}
\hline Characteristic & $\mathbf{1}$ & $\mathbf{2}$ & $\mathbf{3}$ & $\mathbf{4}$ & $\mathbf{5}$ & $\mathbf{6}$ & $\mathbf{7}$ & $\mathbf{8}$ & $\mathbf{9}$ \\
\hline Fermentation of: & & & & & & & & & \\
Glucose & + & - & + & $\mathrm{V}$ & - & - & - & $\mathrm{w} /-$ & - \\
Galactose & + & $\mathrm{ND}$ & $\mathrm{w} /-$ & $\mathrm{V}$ & - & - & - & - & - \\
Assimilation of: & & & & & & & & & \\
Cellobiose & + & - & - & - & - & + & - & - & + \\
Maltose & + /W & - & - & - & - & - & - & + & - \\
D-Mannitol & + & + & + & $\mathrm{V}$ & + & + & + & + & + \\
Ribitol & + & - & $\mathrm{V}$ & $\mathrm{V}$ & - & - & $\mathrm{V}$ & - & $\mathrm{V}$ \\
Sucrose & $\mathrm{W}$ & - & - & - & - & - & - & - & - \\
Trehalose & $\mathrm{W}$ & - & - & - & - & - & - & - & - \\
D-Xylose & + & + & + & + & + & + & + & + & + \\
& & & & & & & & & \\
\hline
\end{tabular}

using BioNumerics version 4.5 (Applied Maths). Unknown bases were discarded for the analysis. The statistical reliability of the topology of the phylogenetic trees was evaluated using bootstrap resampling of the data (1000 resamplings) (Figs 2, 3 and 4).

Additionally, the isolates and their closest phylogenetic neighbours were genotypically investigated by Repetitive Element Palindromic (rep)-PCR using the primer GTG $_{5}$ (5'-GTGGTGGTGGTGGTG-3') as previously described (Andrade et al., 2006; Nielsen et al., 2007). Isolate G3 ${ }^{\mathrm{T}}$ (group A) was clearly separated $(r \leqslant 68 \%)$ from type strains representing the phylogenetically closest relatives (see Supplementary Fig. S1 in IJSEM Online). Isolates G6 ${ }^{\mathrm{T}}$ and G17 (group B) clustered closely together $(r>90 \%)$ and were only distantly related $(r \leqslant 52 \%)$ to type strains representing the phylogenetically closest relatives (see Supplementary Fig. S2). Isolates $\mathrm{G}^{\mathrm{T}}{ }^{\mathrm{T}}, \mathrm{G} 68, \mathrm{G} 71$ and G174 (group C) formed two closely related $(r=82 \%)$ but distinct groups with the four isolates clearly clustering $(r=61 \%)$ away from the closest phylogenetic relatives (see Supplementary Fig. S3).

Based on the above data, it can be concluded that strain $\mathrm{G}^{\mathrm{T}}$ is genetically and phenotypically distinct from all currently recognized species with $S$. mendoncae and $S$. ahearnii being the closest phylogenetic relatives. Phenotypically, strain $\mathrm{G}^{\mathrm{T}}$ can be differentiated from the closest phylogenetic neighbours on the basis of its ability to assimilate cellobiose, D-xylose and maltose (slow reaction) as seen from Table 1. The results obtained in the present study clearly indicate that strain $\mathrm{G}^{\mathrm{T}}$ represent a novel species that is genetically closely related to the genus Saturnispora. However, as ascospore production was not
Table 3. Key phenotypic characteristics of Candida awuaii sp. nov. and its closest phylogenetic relatives

Taxa; 1, Candida awuaii sp. nov.; 2, Candida rugopelliculosa; 3, Pichia occidentalis; 4, Pichia exigua. +, Positive; -, negative; v, variable, strain dependent; s, slow; w, weak. Data partially adopted from Kurtzman (1998b) and Meyer et al. (1998).

\begin{tabular}{|lcccc|}
\hline Characteristic & $\mathbf{1}$ & $\mathbf{2}$ & $\mathbf{3}$ & $\mathbf{4}$ \\
\hline Fermentation of maltose & + & - & - & - \\
Assimilation of: & & & & \\
Cellobiose & + & - & - & - \\
Maltose & $\mathrm{V}$ & - & - & - \\
Ribitol & $\mathrm{V}$ & - & - & - \\
Sucrose & $\mathrm{S}$ & - & - & - \\
Trehalose & $\mathrm{V}$ & - & - & - \\
D-Xylose & W & - & - & + \\
& & & & \\
\hline
\end{tabular}

observed in the new isolate, the novel species must belong to the anamorphic ascomycetous yeasts. The name Candida halmiae sp. nov. is proposed for the new isolate, with strain $\mathrm{G}^{\mathrm{T}}\left(=\mathrm{CBS} 11009^{\mathrm{T}}=\right.$ CCUG $\left.56721^{\mathrm{T}}\right)$ being the type strain.

Isolates $\mathrm{G}^{\mathrm{T}}$ and $\mathrm{G} 17$ formed a genetically and phenotypically distinct group that was most closely related to $D$. albidus, D. geniculatus and D. australiensis but as ascospore formation was not observed, the isolates belong to the anamorphic ascomycetous yeasts. Phenotypically, the ability to ferment galactose and assimilate sucrose and trehalose differentiated strains $\mathrm{G}^{\mathrm{T}}$ and $\mathrm{G} 17$ from their closest phylogenetic neighbours (Table 2). The results obtained in the present study clearly indicate that isolates $\mathrm{G6}^{\mathrm{T}}$ and G17 represent a novel species in the anamorphic genus Geotrichum, for which we propose the name Geotrichum ghanense sp. nov. with strain G6 $^{\mathrm{T}}(=\mathrm{CBS}$ $11010^{\mathrm{T}}=$ CCUG $56722^{\mathrm{T}}$ ) being the type strain.

Isolates $\mathrm{G} 15^{\mathrm{T}}$, G68, G71 and G174 formed a genetic and phenotypic distinct group phylogenetically closest related to C. rugopelliculosa, $P$. occidentalis and $P$. exigua. Phenotypically, the ability to ferment maltose and assimilate cellobiose and ribitol clearly differentiated strains $\mathrm{G}^{\mathrm{T}}{ }^{\mathrm{T}}, \mathrm{G} 68, \mathrm{G} 71$ and G174 from their closest phylogenetic neighbours (Table 3). In conclusion, the results obtained in the present study clearly indicate that isolates $\mathrm{G} 15^{\mathrm{T}}$, G68, G71 and G174 represent a novel species in the genus Candida, for which we propose the name Candida awuaii sp. nov. with strain $\mathrm{G}^{\mathrm{T}}{ }^{\mathrm{T}} \quad(=\mathrm{CBS}$ $11011^{\mathrm{T}}=$ CCUG $56723^{\mathrm{T}}$ ) being the type strain.

\section{Latin diagnosis of Candida halmiae Nielsen, Jakobsen et Jespersen sp. nov.}

In liquido $\mathrm{YM}$, post dies $1-3$ ad $25^{\circ} \mathrm{C}$, cellulae vegetativae ovoidae $(2.5-5.0 \mu \mathrm{m} \times 3.8-7.5 \mu \mathrm{m})$, singulae aut binae. Per gemmationem multipolarem reproducentes. In agaro MYGP post dies $4-6$ ad $25{ }^{\circ} \mathrm{C}$ cultura $2-3 \mathrm{~mm}$, candida et cremea, 


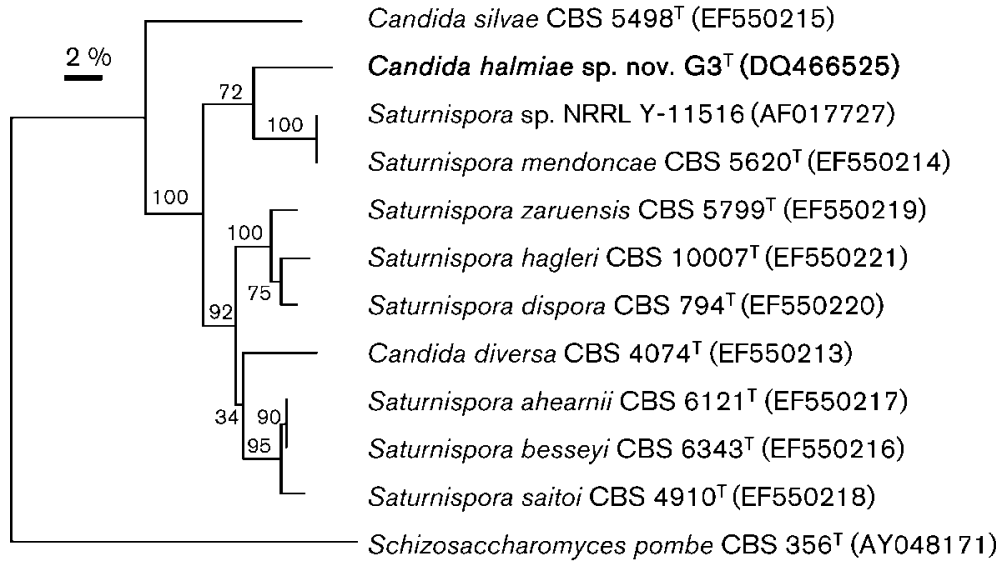

Fig. 2. Phylogenetic tree (neighbour-joining method) based on almost complete $26 \mathrm{~S}$ rRNA gene sequences (D1/D2 region) showing the phylogenetic position of isolate $\mathrm{G}^{\top}{ }^{\top}$ (GenBank accession nos in parentheses). Schizosaccharomyces pombe was included as the outgroup. Bootstrap values (\%) based on 1000 replications are given on each node. Bar, $2 \%$ sequence divergence. butyrosa, glabra, infima-convexa et margo integra. Ascosporae non formantur. Glucosum et maltosum fermentatur. Sucrosum, D-galactosum, D-trehalosum, D-lactosum, D-raffinosum non fermentatur. Assimilantur D-glucosum, ribitolum (exigue), D-xylosum (exigue), cellobiosum (exigue), D-mannitolum, maltosum (exigue), trehalosum (exigue), et DL-acidum lacticum. Non assimalatur L-sorbosum, sucrosum, D-galactosum, D-sorbitolum, D-ribosum, N-acetylglucosaminum, L-rhamnosum, L-arabinosum, erythritolum, D-raffinosum, D-melibiosum, D-melezitosum, 2-ketogluconatum, gluconatum, methyl D-pyranosidium, D-lactosum, inositolum et glycerolum. Non assimalatur nitratum. Aesculinum hydrolysatur. Crescentiae (exigue) $37^{\circ} \mathrm{C}$. Typus $\mathrm{G} 3^{\mathrm{T}}$ $\left(=\right.$ CBS $11009^{\mathrm{T}}=$ CCUG $\left.56721^{\mathrm{T}}\right)$.

\section{Description of Candida halmiae Nielsen, Jakobsen \& Jespersen sp. nov.}

Candida halmiae (hal'mi.ae. N.L. fem. gen. n. halmiae of Halm, named in honour of Dr Mary Halm, a Ghanaian microbiologist who has contributed significantly to our understanding of the importance of yeasts in indigenous African fermented foods).

In YM and YGP broth after $1-3$ days at $25{ }^{\circ} \mathrm{C}$, cells are ovoidal $(2.5-5.0 \mu \mathrm{m} \times 3.8-7.5 \mu \mathrm{m})$, occur singly and in pairs, and divide by multilateral budding. On YPG and MYGP agar (4-6 days, $25^{\circ} \mathrm{C}$ ) colonies are circular with a diameter of 2-3 mm, tannish-white, butyrous, smooth, glistering, low convex and with an entire margin. Formation of ascospores is not observed. Glucose and maltose are fermented. Sucrose, D-galactose, trehalose, lactose and raffinose are not fermented. Glucose, ribitol (weak), D-xylose (slow), cellobiose (slow), D-mannitol, maltose (slow), trehalose (weak) and DL-lactic acid are assimilated. L-Sorbose, sucrose, D-galactose, D-sorbitol, D-ribose, $\mathrm{N}$-acetylglucosamine, L-rhamnose, L-arabinose, erythritol, raffinose, melibiose, melezitose, 2-ketogluconate, gluconate, methyl D-glucopyranoside, D-lactose, inositol and glycerol are not assimilated. Aesculin is hydrolysed. Nitrate is not assimilated. No growth in the presence of $0.01 \%$ cycloheximide. Grows at $37{ }^{\circ} \mathrm{C}$, but growth is weak and delayed.

The type strain, G3 ${ }^{\mathrm{T}}\left(=\mathrm{CBS} 11009^{\mathrm{T}}=\mathrm{CCUG} 56721^{\mathrm{T}}\right.$ ), was isolated from cocoa fermentations in Tafo, Ghana. The description of the type strain corresponds to the description of the species.

\section{Latin diagnosis of Geotrichum ghanense Nielsen, Jakobsen et Jespersen sp. nov.}

In liquido YM, post dies $1-5$ ad $25{ }^{\circ} \mathrm{C}$ pellicula formantur et cellulae ovoidae aut elongatae $(3.5-6.3 \times 6.3-12.5 \mu \mathrm{m})$, singulae authyphae. Hyphae ramosae cum arthroconidiis formantur. In agaro MYGP post dies 4 ad $25{ }^{\circ} \mathrm{C}$ cultura 5$10 \mathrm{~mm}$, candida, farinosus, margine ciliata. Ascosporae non

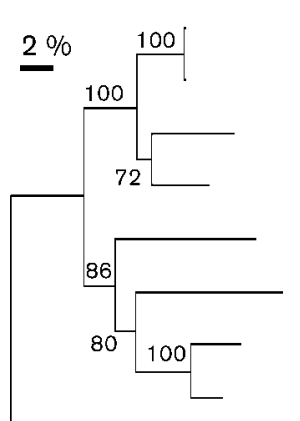

Endomyces decipiens CBS 165.29 (U40129)

Dipodascus armillariae CBS $817.71^{\top}$ (U40093)

Dipodascus macrosporus CBS $259.82^{\top}$ (U40121)

Geotrichum klebahnii CBS $179.30^{\top}$ (U40114)

Geotrichum ghanensis sp. nov. $\mathrm{G}^{\top}{ }^{\top}$ (DQ466527)

Dipodascus australiensis CBS $625.74^{\top}$ (U40100)

Dipodascus geniculatus CBS $184.80^{\top}$ (U40130)

Dipodascus albidus CBS $766.85^{\top}$ (U40081)

Schizosaccharomyces pombe CBS $356^{\top}$ (AY048171)
Fig. 3. Phylogenetic tree (neighbour-joining method) based on almost complete $26 \mathrm{~S}$ rRNA gene sequences (D1/D2 region) showing the phylogenetic position of isolate $\mathrm{G}^{\top}$. For further details, see Fig. 2. 


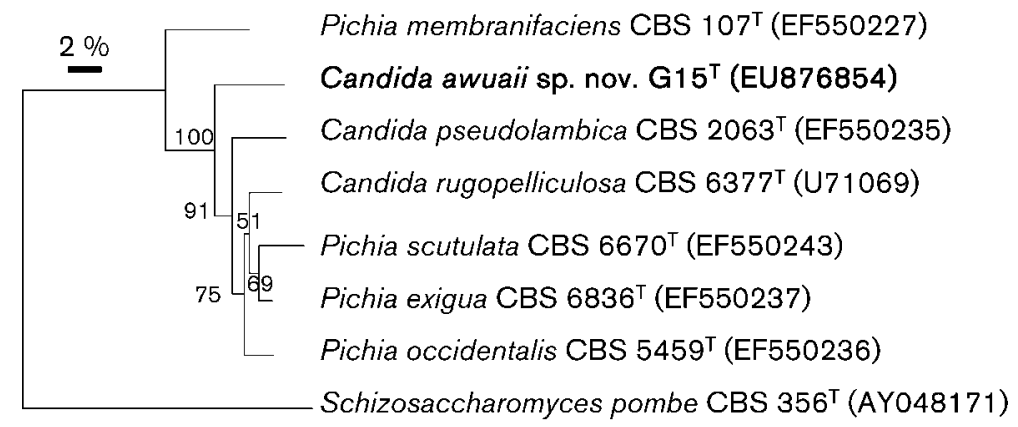

Fig. 4. Phylogenetic tree (neighbour-joining method) based on almost complete 26S rRNA gene sequences (D1/D2 region) showing the phylogenetic position of isolate $\mathrm{G} 15^{\top}$. For further details, see Fig. 2.

formantur. Glucosum et D-galactosum fermentatur. Sucrosum, maltosum, D-trehalosum, D-lactosum, D-raffinosum non fermentatur. Assimilantur D-glucosum, L-sorbosum, ribitolum (exigue), sucrosum (exigue), maltosum (exigue), Dxylosum, cellobiosum, D-mannitolum, trehalosum (exigue), D-galactosum glycerolum et levulitum. Non assimalatur Dribosum, $N$-acetylglucosaminum, L-rhamnosum, L-arabinosum, D-raffinosum, D-melibiosum, gluconatum, D-melezitosum, 2-ketogluconatum, methyl D-pyranosidium, D-lactosum et inositolum. Assimilantur DL-acidum lacticum variabile. Non assimalatur nitratum. Aesculinum hydrolysatur. Crescentiae $37^{\circ} \mathrm{C}$. Typus $\mathrm{G}^{\mathrm{T}} \quad\left(=\mathrm{CBS} \quad 11010^{\mathrm{T}}=\mathrm{CCUG}\right.$ $56722^{\mathrm{T}}$ ) non assimalatur DL-acidum lacticum.

\section{Description of Geotrichum ghanense Nielsen, Jakobsen \& Jespersen sp. nov.}

Geotrichum ghanense (ghan.en'se. N.L. neut. adj. ghanense pertaining to Ghana where the organism was first isolated).

A pellicle is formed in YM and YGP broth after 1-5 days at $25{ }^{\circ} \mathrm{C}$. Cells are ovoid to elongate $(3.5-6.3 \times 6.3-12.5 \mu \mathrm{m})$ occurring singly and as hyphae disarticulating into arthroconidia. On YPG and MYGP agar $\left(4\right.$ days, $\left.25^{\circ} \mathrm{C}\right)$, true mycelium with branching hyphae is produced. Colonies are 5-10 $\mathrm{mm}$ in diameter, whitish, dry, farinose and with creeping hyphae. Formation of ascospores is not observed. Glucose and galactose are fermented. Sucrose, trehalose, lactose, maltose and raffinose are not fermented. Glucose, L-sorbose, ribitol, sucrose (weak), maltose (weak), D-xylose, cellobiose, D-mannitol, trehalose (weak), galactose, levulinate and glycerol are assimilated. D-Ribose, $\mathrm{N}$ acetylglucosamine, L-rhamnose, L-arabinose, raffinose, melibiose, gluconate, melezitose, 2-ketogluconate, methyl D-glucopyranoside, lactose, inositol and glucosamine are not assimilated. Assimilation of DL-lactic acid is strain dependent. Nitrate is not assimilated. Aesculin is hydrolysed. Able to grow in the presence of $0.01 \%$ cycloheximide. Growth occurs at $37^{\circ} \mathrm{C}$.

The type strain, $6^{\mathrm{T}}\left(=\mathrm{CBS} 11010^{\mathrm{T}}=\mathrm{CCUG} 56722^{\mathrm{T}}\right)$, and all other known strains were isolated from cocoa fermentations in Tafo, Ghana. The description of the type strain corresponds to the description the species, except that the type strain does not assimilate DL-lactic acid.

\section{Latin diagnosis of Candida awuaii Nielsen, Jakobsen et Jespersen sp. nov.}

In liquido $\mathrm{YM}$, post dies $2-5$ ad $25{ }^{\circ} \mathrm{C}$, cellulae vegetativae ovoidae $(2.5-3.8 \mu \mathrm{m} \times 3.8-6.3 \mu \mathrm{m})$, singulae, binae et aggregatae. Per gemmationem multipolarem reproducentes. In agaro MYGP post dies 4 ad $25{ }^{\circ} \mathrm{C}$ cultura $2-3 \mathrm{~mm}$, candida et cremea, butyrosa, convexa et margo non integra. Ascosporae non formantur. Glucosum et maltosum fermentatur. Sucrosum, D-galactosum, D-trehalosum, D-lactosum, D-raffinosum non fermentatur. Assimilantur D-glucosum, glycoroleum, D-xylosum (exigue), cellobiosum (exigue), Lsorbosum (exigue), sucrosum (exigue). Non assimalatur Dgalactosum, N-acetylglucosaminum, D-sorbitolum, L-rhamnosum, L-arabinosum, erythritolum, D-raffinosum, D-melibiosum, D-melezitosum, 2-ketogluconatum, gluconatum, methyl D-pyranosidium, D-lactosum, inositolum et glucosaminium. Assimilantur maltosum (exigue), ribitolum, Dmannitolum et trehalosum variabile. Non assimalantur nitratum. Aesculinum hydrolysatur. Crescentiae (exigue) $37^{\circ} \mathrm{C}$. Typus $\mathrm{G} 15^{\mathrm{T}} \quad\left(=\mathrm{CBS} \quad 11011^{\mathrm{T}}=\right.$ CCUG $\left.56723^{\mathrm{T}}\right)$ assimilantur ribitolum et trehalosum; D-mannitolum non assimilatur.

\section{Description of Candida awuaii Nielsen, Jakobsen \& Jespersen sp. nov.}

Candida awuaii (a.wuai'i. N.L. masc. gen. n. awuaii of Awua, named in honour of Dr Wisdom K. Amoa-Awua, a Ghanaian microbiologist who has contributed significantly to our understanding of the importance of yeasts in indigenous African fermented foods).

In YM and YGP broth after $2-5$ days at $25^{\circ} \mathrm{C}$, cells are ovoid (2.5-3.8 $\mu \mathrm{m} \times 3.8-6.3 \mu \mathrm{m})$, divide by multilateral budding, occur singly, in pairs and form chains and star-like aggregates. On MYGP agar ( 4 days, $25{ }^{\circ} \mathrm{C}$ ) colonies are $2-$ $3 \mathrm{~mm}$ in diameter, tannish-white, circular, butyrous, convex and with a slightly fringed margin. After 14 days the colony edge is fringed and the centre of the colonies becomes yellowish. Formation of ascospores is not observed. Glucose and maltose are fermented. Sucrose, galactose, trehalose, lactose, and raffinose are not fermented. Glucose, cellobiose, L-sorbose (weak), sucrose (slow), D-xylose (weak) and glycerol are assimilated. Galactose, D-sorbitol, $N$-acetylglu- 
cosamine, L-rhamnose, L-arabinose, erythritol, raffinose, melibiose, melezitose, 2-ketogluconate, gluconate, methyl Dglucopyranoside, lactose, inositol and glucosamine are not assimilated. Assimilation of maltose (slow), ribitol, Dmannitol (slow) and trehalose (slow) are strain dependent. Nitrate is not assimilated. No growth in the presence of $0.01 \%$ cycloheximide. Growth occurs at $37{ }^{\circ} \mathrm{C}$.

The type strain, $\mathrm{G} 15^{\mathrm{T}}\left(=\mathrm{CBS} 11011^{\mathrm{T}}=\mathrm{CCUG} 56723^{\mathrm{T}}\right)$, and all other known strains of the species have been isolated from cocoa fermentations in Tafo, Ghana. The description of the type strain corresponds to the description the species except that ribitol (slow) and trehalose (slow) are assimilated and D-mannitol is not assimilated.

\section{Acknowledgements}

The work performed was partly financed through the EU INCO project: 'Developing biochemical and molecular markers for determining quality assurance in the primary processing of cocoa in West Africa - COCOQual' (ICA4-CT-2002-10040). The cooperation of the Cocoa Research Institute of Ghana (Dr J. S. Takrama) and the excellent technical assistance of Janne Benjaminsen are highly appreciated.

\section{References}

Altschul, S. F., Madden, T. L., Schäffer, A. A., Zhang, J., Zhang, Z., Miller, W. \& Lipman, D. J. (1997). Gapped BLAST and PSI-BLAST: a new generation of protein database search programs. Nucleic Acids Res $\mathbf{2 5}$ 3389-3402.

Andrade, M. J., Rodriguez, M., Sánchez, B., Aranda, E. \& Córdoba, J. J. (2006). DNA typing methods for differentiation of yeasts related to dry-cured meat products. Int J Food Microbiol 107, 48-58.

de Hoog, G. S., Smith, M. T. \& Guého, E. (1998a). Dipodascus de Lagerheim. In The Yeasts - a Taxonomic Study, pp. 181-193. Edited by C. P. Kurtzman \& J. W. Fell. Amsterdam: Elsevier.

de Hoog, G. S., Smith, M. T. \& Guého, E. (1998b). Galactomyces Redhead \& Malloch. In The Yeasts - a Taxonomic Study, pp. 209-213. Edited by C. P. Kurtzman \& J. W. Fell. Amsterdam: Elsevier.

de Hoog, G. S., Smith, M. T. \& Guého, E. (1998c). Geotrichum Link: Fries. In The Yeasts - a Taxonomic Study, pp. 574-579. Edited by C. P. Kurtzman \& J. W. Fell. Amsterdam: Elsevier.
Jespersen, L., Nielsen, D. S., Hønholt, S. \& Jakobsen, M. (2005). Occurrence and diversity of yeasts involved in fermentation of West African cocoa beans. FEMS Yeast Res 5, 441-453.

Kurtzman, C. P. (1998a). Saturnispora Liu \& Kurtzman. In The Yeasts - a Taxonomic Study, pp. 387-390. Edited by C. P. Kurtzman \& J. W. Fell. Amsterdam: Elsevier.

Kurtzman, C. P. (1998b). Issatchenkia Kudryavtsev emend. Kurtzmann, Smiley \& Johnson. In The Yeasts - a Taxonomic Study, pp. 221-226. Edited by C. P. Kurtzman \& J. W. Fell. Amsterdam: Elsevier.

Kurtzman, C. P. (2006). New species and new combinations in the yeast genera Kregervanrija gen. nov., Saturnispora and Candida. FEMS Yeast Res 6, 288-297.

Kurtzman, C. P., Robnett, C. J. \& Basehoar-Powers, E. (2008). Phylogenetic relationships among species of Pichia, Issatchenkia and Williopsis determined from multigene sequence analysis, and the proposal of Barnettozyma gen. nov., Lindnera gen. nov and Wickerhamomyces gen. nov. FEMS Yeast Res 8, 939-954.

Meyer, S. A., Payne, R. W. \& Yarrow, D. (1998). Candida Berkhout. In The Yeasts - a Taxonomic Study, pp. 454-573. Edited by C. P. Kurtzman \& J. W. Fell. Amsterdam: Elsevier.

Morais, P. B., Lachance, M. A. \& Rosa, C. A. (2005). Saturnispora hagleri sp. nov., a yeast species isolated from Drosophila flies in Atlantic rainforest in Brazil. Int J Syst Evol Microbiol 55, 17251727.

Nielsen, D. S., Teniola, O. D., Ban-Koffi, L., Owusu, M., Andersson, T. \& Holzapfel, W. H. (2007). The microbiology of Ghanaian cocoa fermentations analysed using culture dependent and culture independent methods. Int J Food Microbiol 114, 168-186.

Pimenta, R. S., Alves, P. D. D., Corrêa, A., Jr, Lachance, M. A., Prasad, G. S., Rajaram, Sinha, B. R. R. P. \& Rosa, C. A. (2005). Geotrichum silvicola sp. nov., a novel asexual arthroconidial yeast species related to the genus Galactomyces. Int J Syst Evol Microbiol 55, 497-501.

Robert, V., Groenewald, G., Epping, W., Boekhout, T., Smith, M. \& Stalpers, J. (2008). CBS Yeasts Database. Utrecht, The Netherlands: Centraalbureau voor Schimmelcultures.

Schwan, R. F. \& Wheals, A. E. (2004). The microbiology of cocoa fermentation and its role in chocolate quality. Crit Rev Food Sci Nutr 44, 205-222.

Yarrow, D. (1998). Methods for the isolation, maintenance and identification of yeasts. In The Yeasts - a Taxonomic Study, 4th edn, pp. 77-100. Edited by C. P. Kurtzman \& J. W. Fell. Amsterdam: Elsevier. 